\title{
Synthesis and Chemical and Biological Evaluation of a Glycine Tripeptide Chelate of Magnesium
}

\author{
Derek R. Case $^{1}$, Jon Zubieta ${ }^{1}\left(\mathbb{D}\right.$, Ren Gonzalez $^{2}$ and Robert P. Doyle ${ }^{1, *(D)}$ \\ 1 Department of Chemistry, 111 College Place, Syracuse University, Syracuse, NY 13244, USA; \\ drcase@syr.edu (D.R.C.); jazubiet@syr.edu (J.Z.) \\ 2 Balchem Corporation, 52 Sunrise Park Road, New Hampton, NY 10958, USA; ren.gonzalez@Balchem.com \\ * Correspondence: rpdoyle@syr.edu
}

check for updates

Citation: Case, D.R.; Zubieta, J.; Gonzalez, R.; Doyle, R.P. Synthesis and Chemical and Biological Evaluation of a Glycine Tripeptide Chelate of Magnesium. Molecules 2021, 26, 2419. https://doi.org/ $10.3390 /$ molecules26092419

Academic Editor: Farkas Etelka

Received: 15 March 2021

Accepted: 18 April 2021

Published: 21 April 2021

Publisher's Note: MDPI stays neutral with regard to jurisdictional claims in published maps and institutional affiliations.

Copyright: (c) 2021 by the authors. Licensee MDPI, Basel, Switzerland. This article is an open access article distributed under the terms and conditions of the Creative Commons Attribution (CC BY) license (https:// creativecommons.org/licenses/by/ $4.0 /)$.
Abstract: Magnesium $\left(\mathrm{Mg}^{2+}\right)$ plays a crucial role in over $80 \%$ of all metabolic functions. It is becoming increasingly apparent that magnesium deficiency (hypomagnesemia) may play an important role in chronic disease. To counteract magnesium deficiency, there is an unmet clinical need to develop new fully characterized, highly bioavailable, and substantially water-soluble magnesium supplements. To this end, triglycine $\left(\mathrm{HG}_{3}\right)$, a tripeptide of the amino acid glycine, was chosen as a chelating ligand for magnesium, given its natural occurrence and water solubility, and entropically-driven metal binding. Herein, we discuss the synthesis, chemical and physical characterization, and cellular uptake of a magnesium triglycine chelate $\left(\mathrm{MgG}_{3}\right)$, an octahedral complex with extraordinary water solubility and improved cellular uptake in CaCo- 2 cells than select commonly used magnesium supplements.

Keywords: magnesium; triglycine; amino acid chelate; solubility; CaCo-2 cells

\section{Introduction}

As the 11th most abundant mineral in the human body, magnesium $\left(\mathrm{Mg}^{2+}\right)$ is a critical micronutrient [1-3]. Magnesium is implicated in over $80 \%$ of metabolic functions and presides over 350 enzymatic processes [1-3]. Of total body $\mathrm{Mg}^{2+}, \sim 99 \%$ is intracellular, with approximately $90 \%$ compartmentalized in bone and muscle, and the remainder $(<1 \%)$ being distributed in plasma and erythrocytes. [4] This distribution of $\mathrm{Mg}^{2+}$ results in blood magnesium concentration being an inaccurate determinant of total body magnesium $[5,6]$. Subsequently, most $\mathrm{Mg}^{2+}$ deficiency (hypomagnesemia-defined as < $0.75 \mathrm{mmol} / \mathrm{L}$ ) [7] goes undiagnosed [8-12].

The prevalence of hypomagnesemia is due, in part, to processed foods having a significantly lowered magnesium content relative to natural crops and grains [13], and an increase in the consumption of such processed foods in the western world [14]. Hypomagnesemia has been linked to a litany of chronic medical conditions including hypertension [15], migraines [16], diabetes mellitus [17], cardiovascular disease [18], and osteoporosis [19-21].

Multiple studies support magnesium supplementation as a viable and generally safe means to treat hypomagnesemia [21-24]. Typical magnesium supplements include magnesium oxide, magnesium chloride, magnesium sulfate, and other organic magnesium formulations (see Table 1). Aqueous solubilities of such supplements vary greatly, from poorly soluble magnesium oxide to more soluble magnesium salts (Table 1).

There is a corollary between the solubility of magnesium compounds and their subsequent bioavailability - the more soluble the supplement, typically, the greater the bioavailability [34-36]. As such, although magnesium oxide is commonly used as a magnesium supplement for its $\sim 60 \%$ magnesium composition, it lacks substantial water solubility and exhibits lower bioavailability than other organic magnesium salts [34,36]. While the chloride and sulfate magnesium salts exhibit substantial water solubility, they rapidly dissociate and leave available reactive sites on the $\mathrm{Mg}^{2+}$ site, making it more susceptible 
to precipitating from bioagents, such as phytates, and hydration-thus resulting in laxation [3,37-39]. As such, biologically relevant chelate ligands are utilized to occupy reactive sites on the magnesium to reduce laxation and increase solubility, subsequently resulting in greater bioavailability. This bioavailability is highly significant, as it will determine magnesium uptake within the body, and is largely dependent on a relatively acidic $\mathrm{pH}$, as magnesium is taken up unequally throughout the length of the small intestine $[37,38,40]$.

Table 1. The aqueous solubilities $(\mathrm{g} / 100 \mathrm{~mL})$ at room temperature, acid/base chemistry, molecular weight, and percent magnesium composition of common magnesium supplements.

\begin{tabular}{|c|c|c|c|c|}
\hline $\begin{array}{c}\text { Form } \\
\text { (Oxide/Salt/Chelate) }\end{array}$ & Acid/Base Chemistry & $\begin{array}{c}\text { Solubility } \\
\left.\text { (g/100 mLs } \mathrm{H}_{2} \mathrm{O}\right)\end{array}$ & MW g/mol (\%Mg) & Reference \\
\hline Magnesium Oxide & Alkaline & 0.010 & $40.30(60.3)$ & [25] \\
\hline Magnesium Citrate & Acidic $\left(\mathrm{pKa}_{1}=3.13\right)$ & 20 & $214.41(11.3)$ & [26] \\
\hline Magnesium Chloride & Neutral & 54.0 & $95.21(25.5)$ & [27] \\
\hline Magnesium Sulfate & Acidic $\left(\mathrm{pKa}_{1}=3.0 ; \mathrm{pKa}_{2}=1.99\right)$ & 35.7 & $120.37(20.1)$ & [25] \\
\hline Magnesium Orotate & Acidic $\left(\mathrm{pKa}_{1}=2.83\right)$ & Slightly Soluble & $334.48(7.2)$ & [28] \\
\hline Magnesium Taurate & Acidic $(\mathrm{pKa}=1.50)$ & Slightly Soluble & $272.57(8.9)$ & [29] \\
\hline Magnesium Aspartate & Acidic $\left(\mathrm{pKa}_{1}=1.88 ; \mathrm{pKa}_{3}=3.65\right)$ & 4.0 & $288.49(8.5)$ & {$[30]$} \\
\hline Magnesium Threonate & Acidic $\left(\mathrm{pKa}_{1}=3.4\right)$ & Soluble & $294.50(8.3)$ & {$[31]$} \\
\hline Magnesium Malate & Acidic $\left(\mathrm{pKa}_{1}=3.46 ; \mathrm{pKa}_{2}=5.10\right)$ & Slightly Soluble & $156.37(15.5)$ & {$[32,33]$} \\
\hline Magnesium Bisglycinate & Acidic $(\mathrm{pKa}=2.34)$ & 1.36 & $172.42(14.1)$ & In-house \\
\hline Magnesium Hydroxide & Alkaline & 0.00069 & $58.32(41.7)$ & [25] \\
\hline Magnesium Carbonate & Weakly Alkaline & 0.18 & $84.31(28.8)$ & [26] \\
\hline Magnesium Triglycine & Acidic & 169 & $265.50(9.1)$ & This Work \\
\hline
\end{tabular}

The naturally occurring glycine peptide trimer, triglycine (IUPAC: 2-[[2-[(2aminoacetyl) amino]acetyl]amino]acetic acid- $-\mathrm{HG}_{3}$ : not to be confused with trisglycine, three individual glycine monomers bound to a metal ion) [41], isolated from the Ackee (Blighia sapida) seed in 1968 by Fowden et al. [42], was chosen as the magnesium chelate ligand by virtue of several significant characteristics, namely, multiple Lewis base moieties that give rise to entropically favored binding (bidentate, tridentate, or tetradentate), extensive hydrogen bond donors/acceptors-when both free and complexed — offering inherent stability [43], well-understood coordination chemistry through the carboxylic acid moiety [44], weakly acidic character [37]; and evidence indicating a higher achievable plasma concentration than both its monomer and dimer progenitors [45].

Synthesis of a magnesium-triglycine chelate was carried out in water, and the recovered solid was analyzed via thermogravimetric analysis (TGA), differential scanning calorimetry (DSC), elemental analysis (EA), Infrared radiation spectroscopy (FT-IR), 1Dand 2D-nuclear magnetic resonance spectroscopy (NMR), and electrospray ionization mass spectrometry (ESI-MS). Cellular uptake of the magnesium triglycine complex was evaluated in the Human CaCo-2 cell line, as a model for the lower intestine [46] — where the majority of magnesium occurs [1]. Both solid and solution state analyses indicate the successful synthesis of a 6-coordinate octahedral magnesium complex via tetradentate $\mathrm{HG}_{3}$ employing a $\mathrm{N}_{3} \mathrm{O}$ donor set and two bound water molecules. Subsequent charge balance is achieved via a hydroxy anion. Solubility studies show that the $\mathrm{MgG}_{3}$ complex shows substantially increased water solubility at $\mathrm{pH}=7(169 \pm 12.5 \mathrm{~g} / 100 \mathrm{~mL})$ relative to both magnesium salts and other current magnesium nutraceuticals. Cellular uptake studies in a CaCo-2 cell line indicated that $\mathrm{MgG}_{3}$ also shows greater relative total magnesium uptake than magnesium chloride and magnesium bisglycinate, suggesting $\mathrm{MgG}_{3}$ is an excellent lead for novel therapeutic magnesium compounds of this type. 


\section{Results}

2.1. Characterization of $M g G_{3}$

\subsubsection{Electrospray Ionization Mass Spectroscopy}

To determine the presence of the desired product from the synthesis of $\mathrm{MgG}_{3}$, a mass spectrum of the dried $\mathrm{MgG}_{3}$ resuspended in $18 \mathrm{M} \Omega \mathrm{H}_{2} \mathrm{O}$ indicated the presence of the free $\left[\mathrm{HG}_{3}\right]^{1+}$ ligand, and the subsequent sodium adduct $\left[\mathrm{HG}_{3} \cdot \mathrm{Na}\right]^{+}$predicted at $190 \mathrm{~m} / z$ and $212 \mathrm{~m} / \mathrm{z}$, respectively, as well as presence of the monoaqua triglycine magnesium chelate $\left[\mathrm{MgG}_{3}+\mathrm{H}_{2} \mathrm{O}\right]^{+}$and the subsequent sodium adduct $\left[\mathrm{MgG}_{3}+\mathrm{H}_{2} \mathrm{O}+\mathrm{Na}\right]^{+}$at $230 \mathrm{~m} / z$ and $252 \mathrm{~m} / \mathrm{z}$, respectively, as indicated by Figure 1 .

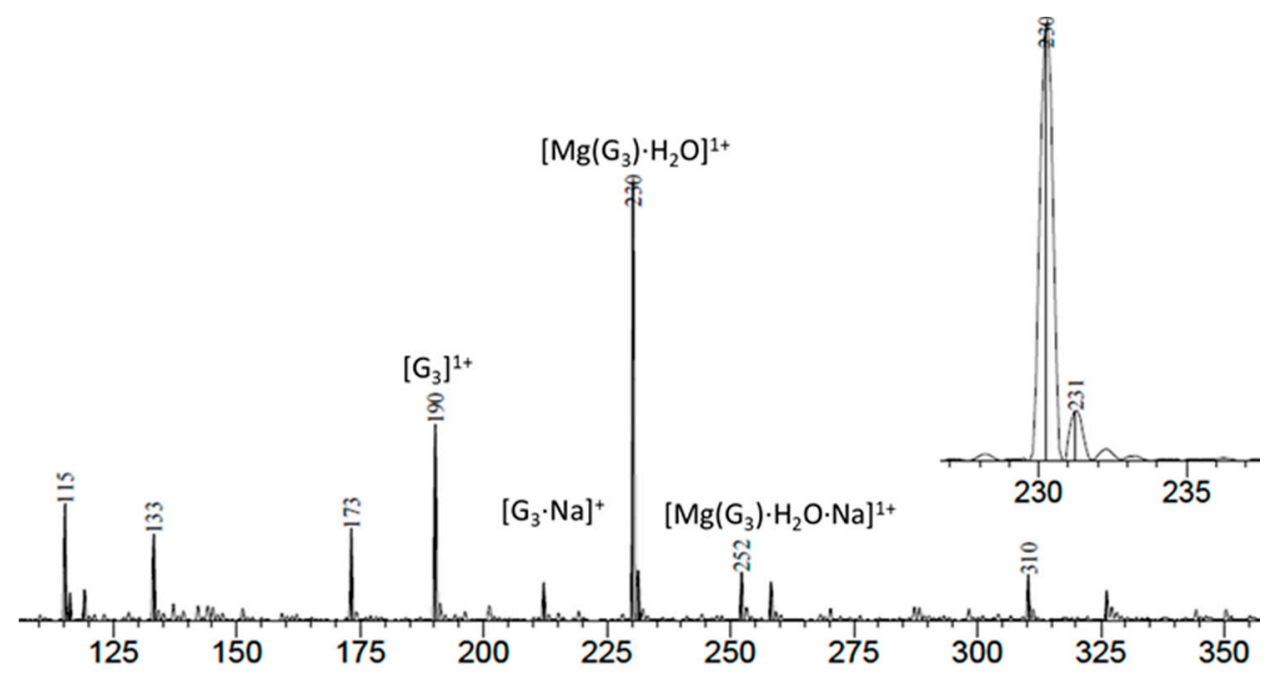

Figure 1. ESI-MS of $\mathrm{MgG}_{3}$ indicating the presence of both the free $\mathrm{HG}_{3}$ ligand as well as the chelate $\mathrm{HG}_{3}$ ligand. Inset at right exhibits the appropriate isotopic distribution pattern of a magnesium chelate.

\subsubsection{Structural Characterization of $\mathrm{MgG}_{3}$ via ${ }^{1} \mathrm{H}-\mathrm{NMR}$ and $2 \mathrm{D}{ }^{1} \mathrm{H} /{ }^{13} \mathrm{C}$ HSQC / HMBC NMR}

It is well established, in the literature, that divalent metal amino acid chelates exhibit ligand chelation predominantly through the carboxylic acid hydroxyl group and the nearest amine (e.g., glycine and glutamate) [43,44], but entropically-favored tri- and tetradentate complexes will occur primarily (e.g., aspartate) [44]. Ligand chelation to magnesium typically results in an observable shift of the proton signals adjacent to the Lewis bases of the free ligand that participate in coordination, as a consequence of the electropositive character of the metal [47-49]. Subsequently, ${ }^{1} \mathrm{H}-\mathrm{NMR}$ was conducted on both the free $\mathrm{HG}_{3}$ ligand and purified $\mathrm{MgG}_{3}$ in $700 \mu \mathrm{L}$ of $\mathrm{H}_{2} \mathrm{O} / \mathrm{D}_{2} \mathrm{O}$ (1:6 (v:v)). The uncomplexed $\mathrm{HG}_{3}$ exhibited three singlets at 4.044, 3.914 and $3.786 \mathrm{ppm}$, whereas the $\mathrm{MgG}_{3}$ complex showed an observable shift for each of the proton peaks at 3.967, 3.747, 3.4077, respectively (Figure S6), indicating a confirmed upfield shift of $0.5 \mathrm{ppm}$ for $\mathrm{H}_{1}$ and $0.1 \mathrm{ppm}$ for $\mathrm{H}_{2}$, and a tentative shift of $0.04 \mathrm{ppm}$ assigned to $\mathrm{H}_{3}$ within the realm of experimental error (Figure 2).

With the understanding that the $\mathrm{HG}_{3}$ ligand will coordinate through the carboxylic acid, subsequent ${ }^{1} \mathrm{H}-\mathrm{NMR}$ in a solution of $700 \mu \mathrm{L}$ of DMSO- $\mathrm{d}_{6} / \mathrm{H}_{2} \mathrm{O}(1: 6$ (v:v)) was conducted to determine the coordinative participation of this moiety. It was hypothesized that the free proton of the carboxylic acid, when in the presence of the polar aprotic solvent DMSO, would participate in hydrogen bonding, thus resulting in an observable splitting of the $\mathrm{H}_{3}$ proton signal; when coordinated, the $\mathrm{HG}_{3}$ ligand would lose this carboxylic proton, thus eliminating the presence of an observable proton split. Subsequent ${ }^{1} \mathrm{H}-\mathrm{NMR}$ supported this hypothesis, thus implicating the carboxylic acid moiety as a participant in coordination to the magnesium metal (Figure 3). 
<smiles>CC(N)C(=O)NC(C)(C)C(=O)O</smiles>

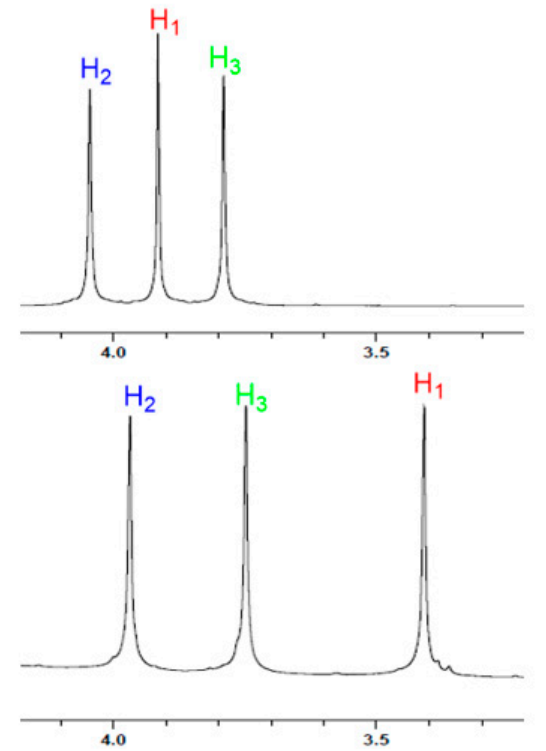

A

B

Figure 2. Proton NMR overlay of $\mathrm{HG}_{3}(\mathbf{A})$ and $\mathrm{MgG}_{3}$ (B) showing the observable upfield shifts of all protons and the subsequent change in proton splitting pattern. Full spectra in Supplemental Figure S7.

A
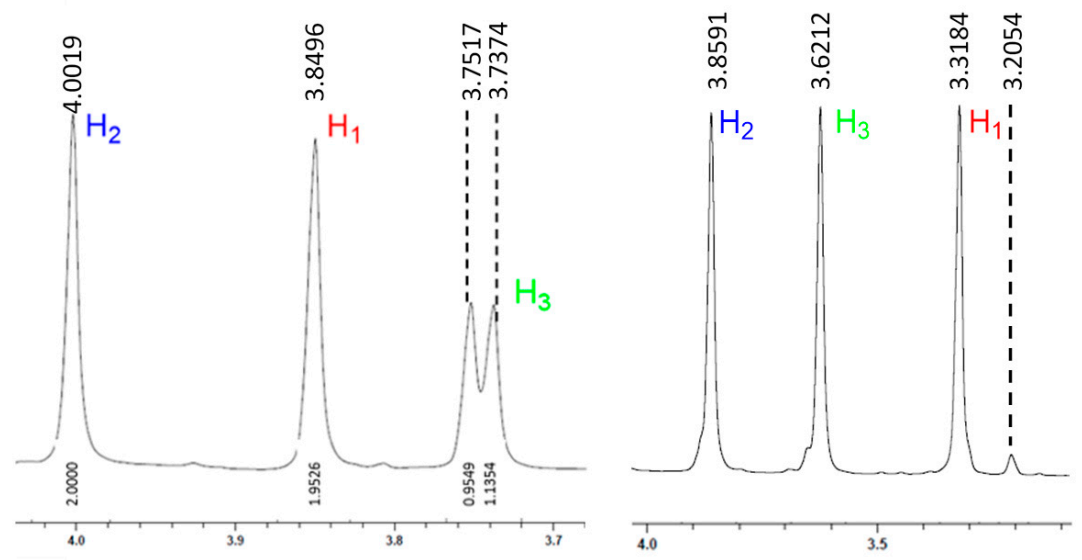

$H_{G_{3}}$

$\mathrm{MgG}_{3}$
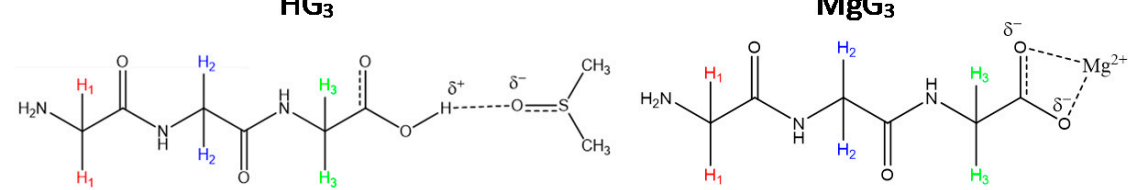

Figure 3. ${ }^{1} \mathrm{H}-\mathrm{NMR}$ of $\mathrm{HG}_{3}$ in DMSO- $\mathrm{d}_{6}(\mathbf{A})$ showing an observable split $(\mathrm{J}=5.7 \mathrm{~Hz})$ of the carboxylic acid proton due to participation in hydrogen bonding, and the ${ }^{1} \mathrm{H}-\mathrm{NMR}$ of $\mathrm{MgG}_{3}$ (B) no longer showing the observable split of the carboxylic acid proton, suggesting that the ligand has coordinated to the magnesium through the carboxylic acid. Full spectra available in Supplementary Figure S9.

To gain further insight into the coordinating moieties of the $\mathrm{HG}_{3}$ ligand, $2 \mathrm{D}$ heteronuclear single quantum coherence (HSQC) and heteronuclear multiple bond correlation (HMBC) were utilized; HSQC and $\mathrm{HMBC}$ of the free $\mathrm{HG}_{3}$ ligand are shown in Figure 4. 
A

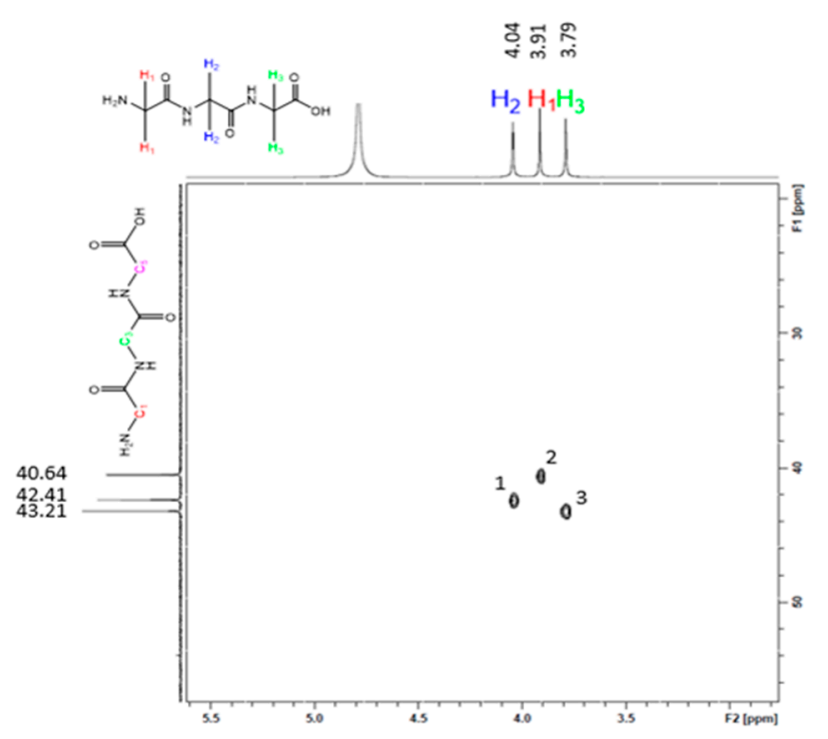

B

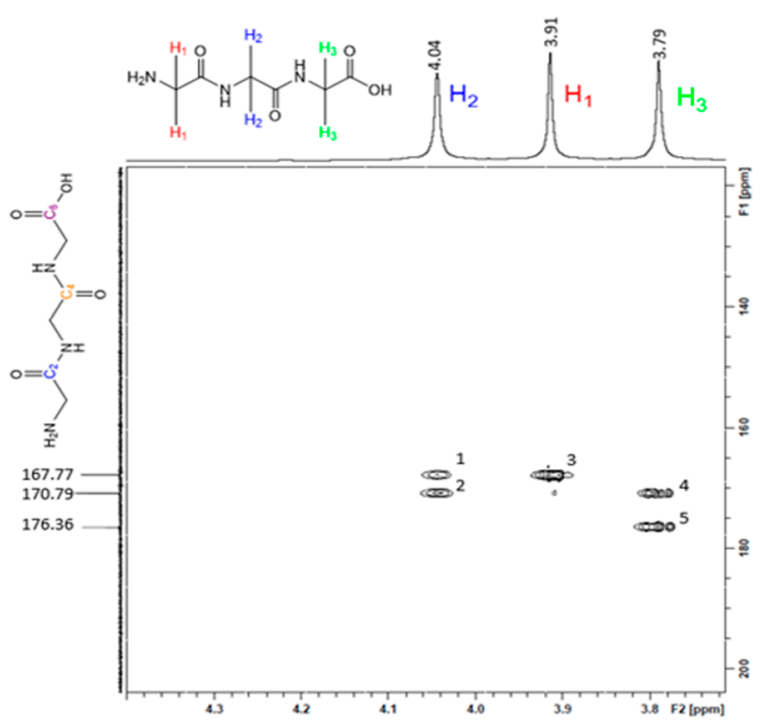

Figure 4. 2D HSQC of $\mathrm{HG}_{3}$ (A) showing a single coherence point between each proton and its corresponding carbon (1:1:1) and the $2 \mathrm{D} \mathrm{HMBC}$ of $\mathrm{HG}_{3}$ (B) showing two correlation points between $\mathrm{H}_{2}$ and two carbons $\left(\mathrm{C}_{2}-167.8 \mathrm{ppm} ; \mathrm{C}_{4}-170.8 \mathrm{ppm}\right)$ and $\mathrm{H}_{3}$ and two carbons $\left(\mathrm{C}_{4}-170.8 \mathrm{ppm} ; \mathrm{C}_{6}-176.4 \mathrm{ppm}\right)$, as well as one correlation point between $\mathrm{H}_{1}$ and one carbon (2:1:2). Full spectra available in Supplemental Figure S10.

Subsequently, 2D HSQC and $\mathrm{HMBC}$ were conducted on $\mathrm{MgG}_{3}$. The most significant change in the spectrum was observed for the $\mathrm{H}_{3}$ proton (Figure 5), which supports that the terminal amine is also involved in magnesium chelation. The combination of both the 1D- and 2D- ${ }^{1} \mathrm{H}-\mathrm{NMR}$ studies suggests that all available Lewis bases of $\mathrm{HG}_{3}$ are coordinated to the magnesium metal via an $\mathrm{N}_{3} \mathrm{O}$ donor set, as the formation of a bidentate ring structure of this size is unlikely and implicates $\mathrm{HG}_{3}$ as a tetradentate chelate with the $\mathrm{Mg}^{2+}$ cation. This is further supported by the presence of a protonated backbone amide stretch [50] observed on the spectra of the $\mathrm{HG}_{3}$ ligand FT-IR that is not observed for the $\mathrm{MgG}_{3}$ complex (Figure S2).
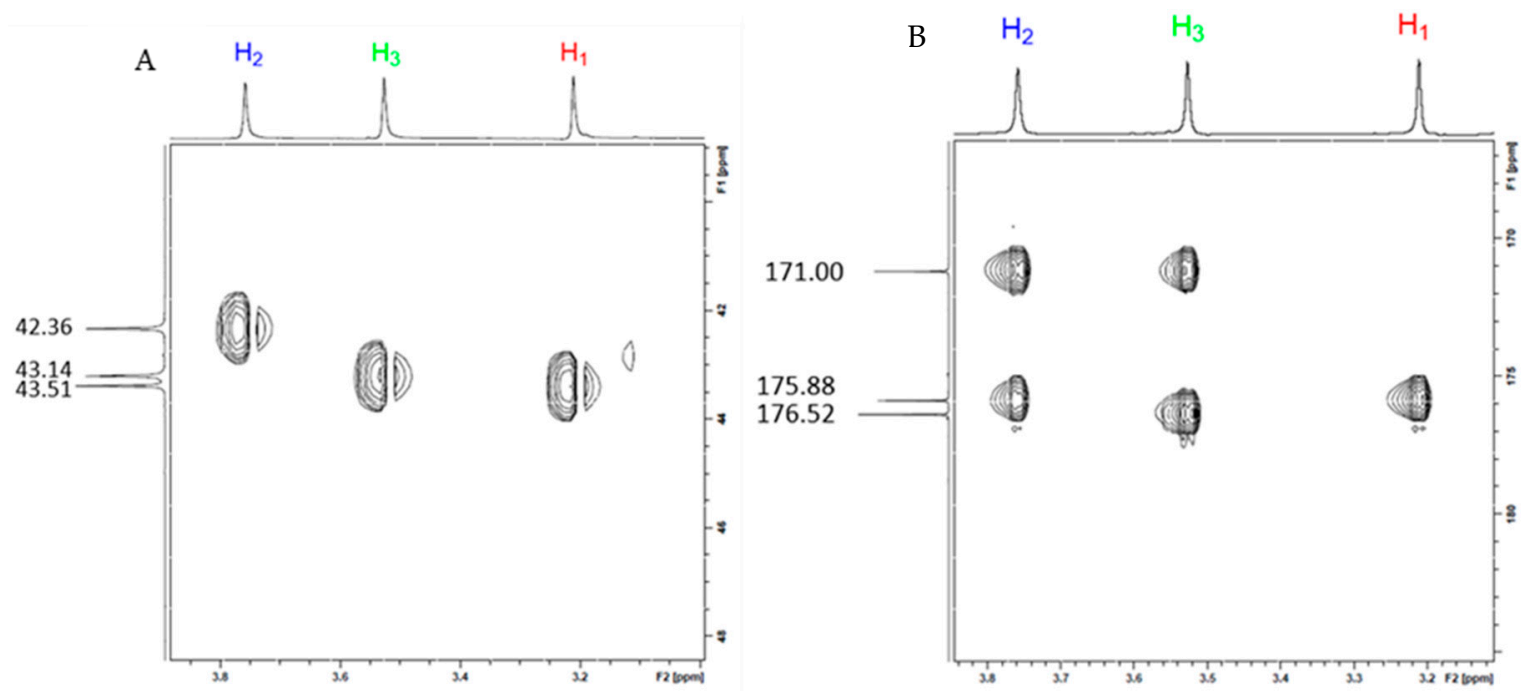

Figure 5. 2D HSQC of $\mathrm{MgG}_{3}$ (A) showing the same observable nuclei points that were observed for the free $\mathrm{HG}_{3}$ ligand and the $\mathrm{HMBC}$ of $\mathrm{MgG}_{3}$ (B) indicating a change in the observable nuclei pattern; the observable nuclei now show a 2:2:1 pattern, which indicates that the $\mathrm{H}_{1}$ proton is now the most upfield shifted proton. Full spectra available in Supplemental Figure S11. 


\subsubsection{Determination of the Chemical Composition of $\mathrm{MgG}_{3}$ via TGA/DSC and EA}

Magnesium characteristically exhibits an extensive hydration sphere [1,51] and assumes a six-coordinate, octahedral geometry-especially in the presence of biologically relevant ligands [52-54]. It was hypothesized then, that the remaining two coordination sites of the magnesium remaining beyond the $\mathrm{HG}_{3}$ ligand donor set $\left(\mathrm{N}_{3} \mathrm{O}\right)$ would be occupied by water, while charge balance would be achieved via a hydroxy anion. To confirm this model, solid state characterization via TGA, DSC, and EA were employed.

The TGA of $\mathrm{MgG}_{3}$ was strikingly different than that of the free $\mathrm{HG}_{3}$ ligand, which exhibited only one continuous weight percent change beginning at approximately $240^{\circ} \mathrm{C}$. $\mathrm{MgG}_{3}$ exhibited three weight percent changes: $6.6 \%$ at $109{ }^{\circ} \mathrm{C}, 14.1 \%$ at $191.5^{\circ} \mathrm{C}$, and one continuous change at approximately $240^{\circ} \mathrm{C}$ (Figure S3). The first weight percent change corresponds to loss of a hydroxy anion-further validated by conductivity which showed a monoanionic character of $\mathrm{MgG}_{3}$. The second weight percent change corresponds to the loss of two coordinating waters from a parent complex of $\left[\mathrm{Mg}\left(\mathrm{G}_{3}\right)\left(\mathrm{H}_{2} \mathrm{O}\right)_{2}\right] \mathrm{OH}$, and the last corresponds to the degradation of the free $\mathrm{HG}_{3}$ ligand. These three independent events were further supported by the presence of three separate observable endotherms on the DSC at 109,191 and $240{ }^{\circ} \mathrm{C}$ (Figure 6).

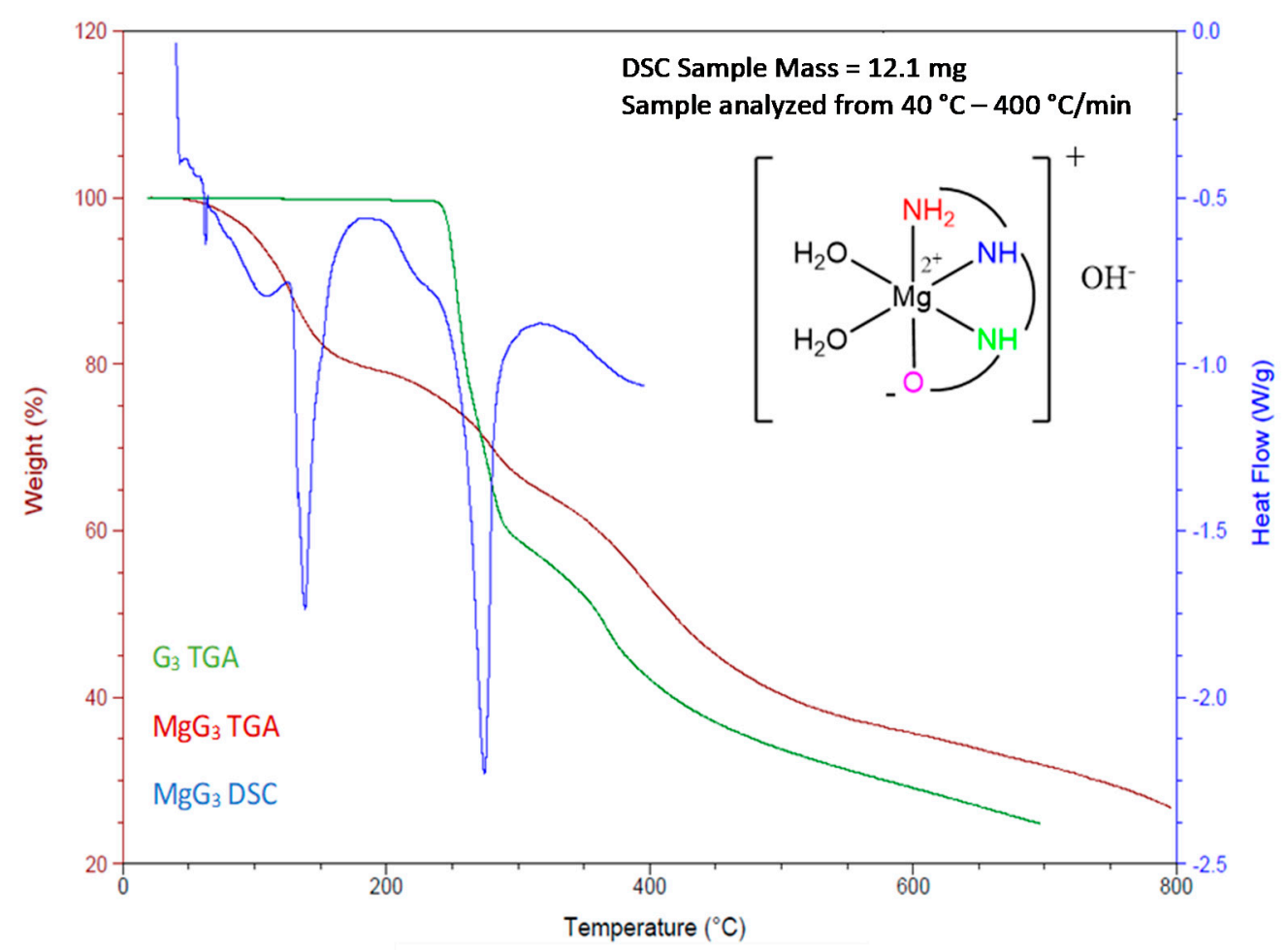

Figure 6. Solid state characterization of $\mathrm{MgG}_{3}$ showing the $\mathrm{TGA}$ of $\mathrm{HG}_{3}$ (green) showing only one continuous weight percent change beginning at $240{ }^{\circ} \mathrm{C}$, the TGA of $\mathrm{MgG}_{3}$ (maroon) showing multiple weight percent changes, further highlighted by the three observable endotherms of the DSC of $\mathrm{MgG}_{3}$ (blue).

The chemical composition of $\mathrm{MgG}_{3}$ was further verified via elemental analysis; replicate analyses were conducted to confirm percent composition. Analysis confirmed a complex of composition $\left[\mathrm{Mg}\left(\mathrm{G}_{3}\right)\left(\mathrm{H}_{2} \mathrm{O}\right)_{2}\right]$ with experimental values as follows: $\mathrm{C}=29.22 \%$, $\mathrm{H}=6.22 \%, \mathrm{~N}=16.03 \%$, which coincide with theoretical values (Figure S5).

\subsubsection{Evaluating the Solubility of $\mathrm{MgG}_{3}$}

Given the important role that solubility plays in magnesium uptake, the potential solubility of $\mathrm{MgG}_{3}$ was a driving interest in exploring $\mathrm{HG}_{3}$ as a magnesium chelate ligand. Over triplicate independent runs, the solubility of $\mathrm{MgG}_{3}$ was found to be $169 \pm 12.5 \mathrm{~g} / 100 \mathrm{~mL}$ $\mathrm{H}_{2} \mathrm{O}$ (see Table 1 ). This solubility of $\mathrm{MgG}_{3}$ is approximately $3 \times$ greater than that of mag- 
nesium chloride, $5 \times$ more soluble than magnesium sulfate, and $8 \times$ more soluble than magnesium citrate-more commonly used magnesium supplementation formulations. Solutions of $\mathrm{MgG}_{3}$ turn a yellow color upon solution saturation. Given previous studies, this increased solubility is believed to be to contribute significantly to the bioavailability of the $\mathrm{MgG}_{3}$ complex. Complex uptake was further evaluated via in vitro analysis in CaCo-2 cells.

\subsection{Cellular Uptake of $\mathrm{MgG}_{3}$}

Cellular uptake of $\mathrm{MgG}_{3}$ was evaluated in CaCo-2 cells relative to $\mathrm{MgCl}_{2}$ and $\mathrm{MgBG}$, utilizing a BioVision colorimetric magnesium uptake assay kit. Cellular uptake data was collected at incubation times of $1 \mathrm{~h}$ (required kit incubation time), $4 \mathrm{~h}$ (the amount of time required for uptake in the GI), and $24 \mathrm{~h}$ (the amount of time required for a complex to clear the GI). It was hypothesized that the exceptional solubility of $\mathrm{MgG}_{3}$ (determined to be $169 \pm 12.5 \mathrm{~g} / 100 \mathrm{~mL}$ over triplicate independent runs), that stems from the coordination of the triamino acid $\mathrm{HG}_{3}$, would result in increased bioavailability and a subsequent increase in cellular uptake. Cellular uptake data indicate that $\mathrm{MgG}_{3}$ exhibits greater cellular uptake than $\mathrm{MgBG}$ and $\mathrm{MgCl}_{2}$ at a significantly lower percent composition of magnesium $(9,14$ and 25\%, respectively) and that uptake maintains linearity (Figures S16 and S18) - uptake relative to \%Mg composition is shown in Supplemental Data (Figure S17). This greater level of uptake was observed at both 1 and $4 \mathrm{~h}$. At $24 \mathrm{~h}$, data indicated that cell saturation had occurred (Figure 7).
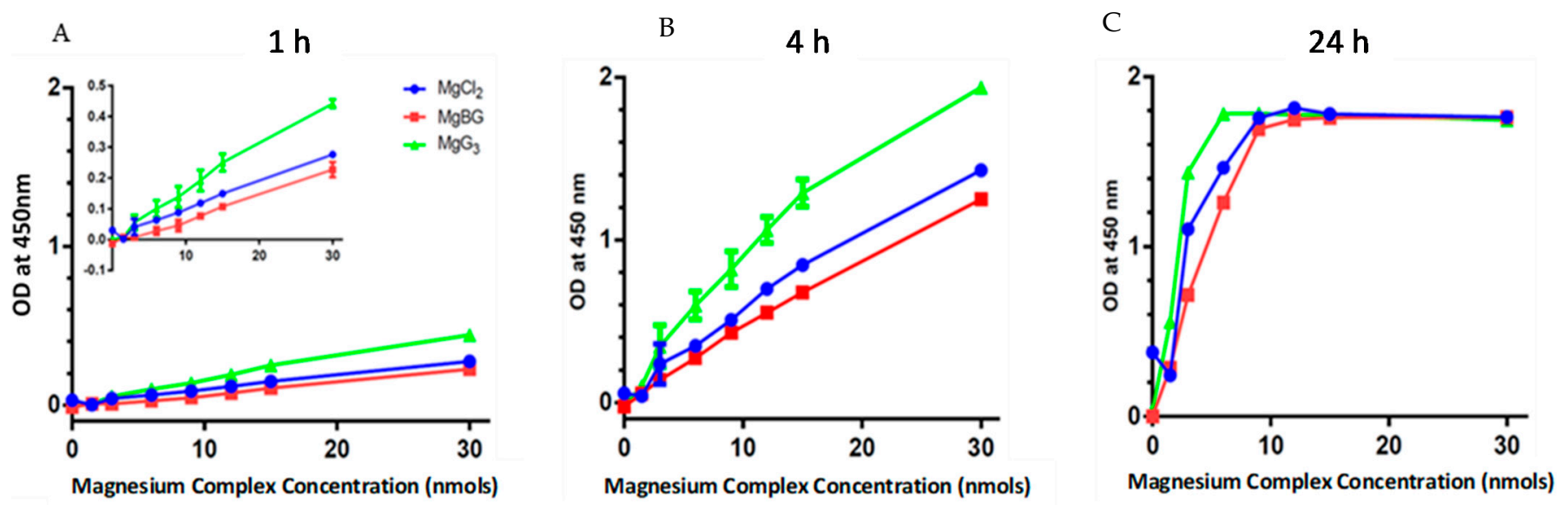

Figure 7. Cellular uptake of $\mathrm{MgG}_{3}$ (green: $\mathbf{9 \%} \mathbf{M g}$ ), $\mathrm{MgBG}$ (red: $\mathbf{1 4} \% \mathbf{M g}$ ), and $\mathrm{MgCl}_{2}$ (blue: $\mathbf{2 5} \% \mathbf{M g}$ ) in CaCo-2 cells analyzed at $1 \mathrm{~h}(\mathbf{A})$ : with included expanded inset), $4 \mathrm{~h} \mathrm{(B),} \mathrm{and} 24 \mathrm{~h}(\mathbf{C})$. Both 1 and $4 \mathrm{~h}$ time points show the increased cellular uptake of $\mathrm{MgG}_{3}$ relative to $\mathrm{MgBG}$ and $\mathrm{MgCl}_{2}$, with $24 \mathrm{~h}$ showing cell saturation.

Kinetic evaluation of cellular uptake was also conducted to determine how uptake of $\mathrm{MgG}_{3}$ compared to that of $\mathrm{MgBG}$ and $\mathrm{MgCl}_{2}$. Kinetics were evaluated utilizing the slope of the line of uptake of the complex in the $\mathrm{CaCo}-2$ cells. Kinetics of uptake were evaluated at 1 and $4 \mathrm{~h}$-kinetics evaluation at $24 \mathrm{~h}$ was not pertinent, due to the observable saturation of the cells indicated by the plateau of the uptake curve at magnesium concentrations greater than 10 nmols. At $1 \mathrm{~h}, \mathrm{MgG}_{3}$ exhibited uptake approximately $1.6 \times$ faster than $\mathrm{MgCl}_{2}$, and approximately $1.9 \times$ faster than that of $\mathrm{MgBG}$. At $4 \mathrm{~h}, \mathrm{MgG}_{3}$ showed uptake that was approximately $1.4 \times$ faster than that of $\mathrm{MgCl}_{2}$, and approximately $1.5 \times$ faster than that of $\mathrm{MgBG}$ (Figure S16). It should also be noted that at $4 \mathrm{~h}, \mathrm{MgG}_{3}$ uptake had plateaued (at $30 \mathrm{nmols}$ ), while both $\mathrm{MgCl}_{2}$ and $\mathrm{MgBG}$ had not. This suggests that $\mathrm{MgG}_{3}$ achieves cellular uptake faster than both $\mathrm{MgCl}_{2}$ and MgBG.

\section{Discussion}

The focus of the work was to produce a fully characterizable, highly soluble magnesium complex that could provide greater bioavailability than current magnesium nutrient 
compounds and be fully characterizable in the solution and solid state to allow for both nutraceutical and pharmaceutical development.

Synthesis of $\mathrm{MgG}_{3}$ was carried out in the presence of citric acid in hopes that it would aid in the solubility of the magnesium oxide starting material by providing a proton source as well allowing the formation of the significantly more soluble magnesium citrate. As was observed, this is the case given the lack of solubility observed for magnesium oxide in solution, and the subsequent increase in observed solubility for the combined solution of magnesium oxide, citric acid, and triglycine. It is believed that after the combination of magnesium oxide, citric acid, and triglycine, that there is a kinetic equilibrium achieved that results in the formation of magnesium triglycine and a trace amount of magnesium citrate, that results in the increased solubility. Syntheses conducted in the citrate buffer $(0.25 \mathrm{M})$, indicated that magnesium citrate predominates, as was determined by ${ }^{1} \mathrm{H}-\mathrm{NMR}$ (Figure S8) and FT-IR (Figure S12). Presence of magnesium citrate indicated that synthesis must be conducted at lower citric acid equivalents - with a quarter equivalent of citric acid determined to be ideal (see Scheme 1). The preliminary synthesis of $\mathrm{MgG}_{3}$ was tracked via ${ }^{1} \mathrm{H}-\mathrm{NMR}$. After two hours, there was no presence of the original three $\mathrm{HG}_{3}$ proton singlets, and no further shifting of the $\mathrm{MgG}_{3}$ proton singlets was observed. These observations indicated that reaction completion was achieved by $2 \mathrm{~h}$. The near stoichiometric yield of the reaction is attributed to the entropic stability of the product-the $\mathrm{HG}_{3}$ ligand.

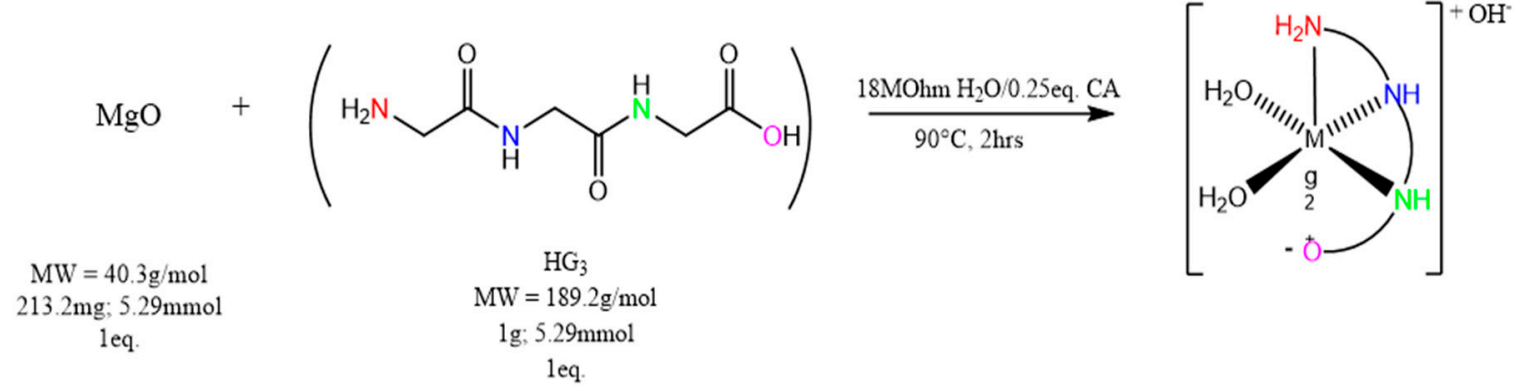

Scheme 1. Synthesis of $\mathrm{MgG}_{3}$ Synthesis was conducted at $1: 1$ molar equivalent of $\mathrm{MgO}$ and $\mathrm{HG}_{3}$, a 0.25 eq of citric acid (CA) was added to aid in MgO solubility.

In view of prior literature on magnesium amino acid chelates, specifically the work of Martell et al., [45] which showed only a single proton displacement of triglycine when titrated into a solution of $\mathrm{Mg}^{2+}$ in the form of magnesium chloride, it was hypothesized that the $\mathrm{HG}_{3}$ ligand would coordinate predominantly through the deprotonated carboxylic acid moiety, which was initially supported using FT-IR (Figure S2) — which coincides with reported literature IR values [55], although alternate coordinating modes were possible given the presence of multiple Lewis bases in the $\mathrm{HG}_{3}$ ligand. Further support for this claim comes from similar observed speciation of triglycine in tin complexes as reported by Jabbari et al. [56] that showed a deprotonation of the carboxylic acid moiety at alkaline $\mathrm{pH}(\geq 8) .{ }^{1} \mathrm{H}$ and ${ }^{13} \mathrm{C}-\mathrm{NMR}$, both $1 \mathrm{D}$ and $2 \mathrm{D}$, were employed to determine what Lewis base moieties were participating in coordination with magnesium. If the magnesium coordinated solely through the carboxylic acid, then only the proton adjacent to the carboxylic acid would show a significantly observable upfield shift. As the data shows, all three proton singlets exhibit an observable upfield shift (Figure 3). Furthermore, ${ }^{1} \mathrm{H}-\mathrm{NMR}$ studies of $\mathrm{HG}_{3}$ and $\mathrm{MgG}_{3}$ in DMSO- $\mathrm{d}^{6}$ showed the absence of proton signal splitting for the proton of the carboxylic acid for the $\mathrm{MgG}_{3}$, indicating that the carboxylic acid has become deprotonated and coordinated to the magnesium metal. Shifting of all proton signals, including the significant upfield shift of the proton adjacent to the terminal amine, and the implication of the carboxylic acid coordination suggests that all available Lewis base moieties have coordinated, thus indicating that the $\mathrm{HG}_{3}$ ligand acts as a tetradentate ligand, which is likely given the observed torsion angles of the free $\mathrm{HG}_{3}$ ligand, that vary by $5-10^{\circ}$ when protonated or deprotonated, as reported by Ivanova et al. [55], and 
as such would be favored entropically. Observed shifting of all proton signals is also consistent with tetradentate ligand coordination as any shift, either upfield or downfield, this is not solely indicative of all Lewis bases participating in magnesium chelation as coordination of magnesium to acids has been shown to exhibit an effect on not only the $\alpha$ proton, but on $\beta$ and $\gamma$ protons as well; with diminishing impact the farther the proton is from the coordination site [47-49]. This conclusion coincides with findings first reported by Martell et al. [57] and later supported by Van der Helm et al. [58] Martell showed, via titration experiments, that $\mathrm{HG}_{3}$ acted as a tetradentate ligand with copper and cobalt [57]. Martell's findings also supported two bound water molecules when in aqueous solution [57]. Van der Helm showed that $\mathrm{HG}_{3}$ also acted as a tetradentate chelate in the presence of calcium via crystal diffraction [58]. Both researchers concluded that the $\mathrm{HG}_{3}$ ligand participated in coordination via an $\mathrm{N}_{3} \mathrm{O}$ donor set [57,58].

Chemical composition determination of $\mathrm{MgG}_{3}$ was carried out utilizing TGA/DSC and elemental analysis. The TGA of both $\mathrm{HG}_{3}$ and $\mathrm{MgG}_{3}$ showed stability until about $240{ }^{\circ} \mathrm{C}$-most likely due to the extensive hydrogen bond network of the ligand as described by Srikrishnan et al. [59].

While there are many physiological factors that have been shown to contribute to magnesium bioavailability during supplementation, such as age [39], dose load [60], and frequency $[61,62]$, there are also chemical factors that impact magnesium bioavailability, such as chemical composition and solubility [34-36,63]. The solubility of $\mathrm{MgG}_{3}$ was found to be approximately $169 \pm 12.5 \mathrm{~g} / 100 \mathrm{~mL} \mathrm{H}_{2} \mathrm{O}$, which is approximately three times more soluble than the next closest magnesium supplement $\left(\mathrm{MgCl}_{2}\right.$ at $54 \mathrm{~g} / 100 \mathrm{~mL}$-see Table 1$)$ and, as such, shows great promise for cellular uptake, as it is believed this increase in solubility will aid in bioavailability. As was hypothesized, the solubility of $\mathrm{MgG}_{3}$ was integral in generating significant cellular uptake-with $\mathrm{MgG}_{3}$ showing greater cellular uptake than both $\mathrm{MgCl}_{2}$ and $\mathrm{MgBG}$ at a lesser overall magnesium percent composition. Additionally, this greater observed uptake may be attributed to complex stability imparted predominantly by the tetradentate $\mathrm{HG}_{3}$ ligand. This increased stability is observed in the significantly decreased percent weight change slope of the $\mathrm{MgG}_{3}$ TGA relative to that of the steeper slope observed for the TGA of the free $\mathrm{HG}_{3}$ ligand, which shows a more rapid decomposition. Further support for $\mathrm{MgG}_{3}$ complex stability comes via ${ }^{1} \mathrm{H}-\mathrm{NMR}$ analysis in 6:1 $\mathrm{H}_{2} \mathrm{O}: \mathrm{D}_{2} \mathrm{O}$ at room temperature. Over a $72 \mathrm{~h}$ period, the ${ }^{1} \mathrm{H}-\mathrm{NMR}$ of $\mathrm{MgG}_{3}$ showed little to no change, suggesting that the complex is maintained for at least this amount of time at room temperature (Figure S19).

With the synthetic ease, solubility, and cellular uptake of the $\mathrm{MgG}_{3}$ complex, it is hypothesized that complexation of the $\mathrm{HG}_{3}$ ligand to other biorelevant, metal ions (e.g., calcium, zinc) may exhibit similar properties. It is further proposed that other tripeptide sequences utilizing an $\mathrm{N}_{3} \mathrm{O}$ donor set may also provide entropic stability and charge balance, thus forgoing the requirement to have a counterion (as is the case of the hydroxy anion described within this work). Removal of ionic character from the overall complex may, in turn, have a profound effect on complex solubility and bioavailability, thus significantly altering cellular uptake. Future work aims at the successful synthesis and characterization of both zinc- and calcium- $\mathrm{G}_{3}$ complexes, and the evaluation of cellular uptake utilizing a $\mathrm{CaCo}-2$ cell line. Subsequently, use of the dianionic tripeptide, Asp-Gly-Asp, as a chelate ligand for magnesium, zinc, and calcium will be conducted, and subsequent cellular uptake evaluated.

\section{Materials and Methods}

\subsection{Materials}

Magnesium oxide (99.99\% metals basis) was purchased through Fisher Scientific (Hampton, NH, USA). Triglycine (Gly-Gly-Gly, BioUltra ${ }^{\mathrm{TM}}, \geq 99.0 \%$ ) and citric acid (ACS Reagent, $\geq 99.5 \%$ ) were purchased through Sigma-Aldrich (St. Louis, MO, USA). 18.2 M $\Omega$ Ultrapure spectroscopic grade water was obtained in-house. $\mathrm{D}_{2} \mathrm{O}$ and DMSO- $\mathrm{d}_{6}$ NMR solvents and 200 proof anhydrous ethanol were purchased from Sigma-Aldrich (St. Louis, 
MO, USA). Potassium bromide (KBr) for FT-IR analysis was purchased from Sigma-Aldrich (St. Louis, MO, USA). Magnesium uptake colorimetric assay kits (includes magnesium enzyme mix, assay developer, and magnesium assay buffer) were purchased from BioVision (Milpitas, CA, USA; Catalog \#385-100). Stock solutions for magnesium uptake assays were made in-house, with $\mathrm{MgCl}_{2}$ (BioReagent, $\geq 97.0 \%$ ) purchased from Sigma-Aldrich (St. Louis, MO, USA) and magnesium bisglycinate (MgBG) provided by Balchem Corp (New Hampton, NY) and confirmed for purity in-house by ${ }^{1} \mathrm{H}-\mathrm{NMR}$ (see Supplemental Figure S1). HEK-293 (ATCC ${ }^{\circledR}$ CRL-1573 ${ }^{\mathrm{TM}}$ ) cells, CaCo-2 (ATCC ${ }^{\circledR}$ HTB-37 ${ }^{\mathrm{TM}}$ ) cells, and Dulbecco's Modified Eagle Medium (ATCC ${ }^{\circledR}$ 30-2002) were purchased from ATCC (Manassus, VA, USA). Penicillin streptomycin (10,000 U/mL), fetal bovine serum (FBS), and trypsin/EDTA $(0.25 \%)$ were purchased from Gibco ${ }^{\mathrm{TM}}$ (Waltham, MA, USA). Clear 96-well Armadillo PCR assay plates (Catalog \#AB2396) were purchased from ThermoFisher (Waltham, MA, USA).

\subsection{Methods}

\subsubsection{Characterization of $\mathrm{MgG}_{3}$}

Electrospray ionization mass spectrometry was carried out on a Shimadzu 8040 LCMS/MS-samples were analyzed utilizing a solvent system of $50 \% \mathrm{H}_{2} \mathrm{O} / 50 \% \mathrm{MeOH} / 0.1 \%$ TFA at a flow rate of $0.2 \mathrm{mLs} / \mathrm{min}$ over a $1.5 \mathrm{~min}$ time frame and evaluated from 0 to $600 \mathrm{~m} / \mathrm{z}$. 1D- and 2D-NMR were conducted on a Bruker Avance III HD $400 \mathrm{MHz}$ instrument. FT-IR was carried out on a Nicolet Infrared Spectrophotometer. TGA was carried out on a TA Instrument Q500 from 20 to $800{ }^{\circ} \mathrm{C}$ with sample weights between 5 and $10 \mathrm{mg}$ (weight percent changes calculated to 6.4 and $14.5 \%$, respectively). DSC was carried out on a TA Instrument Q2000 from 30 to $400{ }^{\circ} \mathrm{C}$ with sample weights between 10 and $20 \mathrm{mg}$. Elemental analysis was conducted by Intertek Pharmaceutical Services (Whitehouse, NJ, USA). Theoretical elemental analysis values are as follows: $\mathrm{C}=29.00 \%, \mathrm{H}=5.68 \%, \mathrm{~N}=16.90 \%$; experimental values are: $\mathrm{C}=29.22 \%, \mathrm{H}=6.22 \%, \mathrm{~N}=16.03 \%$ (Supplemental Figure S5). Uptake of $\mathrm{MgG}_{3}$ in CaCo-2 was determined on a Molecular Devices FlexStation 3 (Molecular Devices). Cellular uptake data was plotted using the Graphpad Prism 8 software.

\subsubsection{Culturing of $\mathrm{CaCo}-2$ and HEK293 Cells}

CaCo-2 cells were cultured from liquid $\mathrm{N}_{2}$ frozen stocks and rapidly thawed to RT using a water bath at $37^{\circ} \mathrm{C}$; cryopreservation media was removed with a micropipette after cells were pelleted via centrifugation for 5-10 min at $125 \mathrm{~g}$. Cells were resuspended in $1 \mathrm{~mL}$ of room temperature Dulbecco's Modified Eagle Medium (DMEM) and cultured in $14 \mathrm{~mL}$ DMEM (total volume of $15 \mathrm{~mL}$ ) with a seeding densities of $3.6 \times 10^{4} \mathrm{cells} / \mathrm{cm}^{2}$ $(\mathrm{CaCo}-2)$ and $6 \times 10^{3}$ cells $/ \mathrm{cm}^{2}$ (HEK 293) in a T-75 $\mathrm{cm}^{2}$ culture flask and left to grow in an incubator at $37{ }^{\circ} \mathrm{C}$ and $5 \% \mathrm{CO}_{2}$. Cells were sub-cultured at $90 \%$ confluency, and sub-culturing occurred a minimum of five times before use in uptake assays. When cultures reached $90 \%$ confluency, media was removed and $3 \mathrm{~mL}$ of trypsin/EDTA was added-the trypsinized culture flask was placed back in the incubator for $\sim 10 \mathrm{~min}$ to detach cells. Once detached cells were confirmed under a microscope, the culture flask was rinsed with $6 \mathrm{~mL}$ of fresh media to neutralize the trypsin/EDTA - cells for uptake assays were then counted utilizing a DeNovix CellDrop ${ }^{\mathrm{TM}}$. Once counted, cells were pelleted down via centrifugation at $125 \mathrm{~g}$ for 5-10 $\mathrm{min}$, and the neutralized trypsin-media supernatant was removed. Cells were resuspended in $5 \mathrm{~mL}$ magnesium assay buffer for cellular uptake assay.

\subsection{Synthesis of Magnesium Triglycine $\left(\left[\mathrm{Mg}\left(\mathrm{G}_{3}\right)\left(\mathrm{H}_{2} \mathrm{O}\right)_{2}\right] \mathrm{OH}-\left(\mathrm{MgG}_{3}\right)\right.$}

A $1.0025 \mathrm{~g}$ sample of triglycine $\left(\mathrm{HG}_{3}-5.29 \mathrm{mmol} ; 1\right.$ eq.) was dissolved in $10 \mathrm{~mL}$ of 18.2 $\mathrm{M} \Omega \mathrm{H}_{2} \mathrm{O}$ in a $50 \mathrm{~mL}$ round-bottom flask, with constant stirring at $90^{\circ} \mathrm{C}$. A separate solution of $215.5 \mathrm{mg}$ magnesium oxide ( $\mathrm{MgO}-5.29 \mathrm{mmol} ; 1$ eq.) was taken up in $10 \mathrm{~mL}$ of $18 \mathrm{M} \Omega \mathrm{H}_{2} \mathrm{O}$, with an addition of $253.6 \mathrm{mgs}$ of citric acid (CA- $-25 \mathrm{eq}$ ), constantly stirred and heated to $90{ }^{\circ} \mathrm{C}$. The $\mathrm{MgO} / \mathrm{CA}$ solution was subsequently added to the triglycine solution. Immediately upon addition, the combined solution turned a milky white color, whereupon this became a clear solution after $\sim 20 \mathrm{~min}$ with stirring at $90^{\circ} \mathrm{C}$. The reaction 
was run for $2 \mathrm{~h}$, and then cooled to room temperature. The $\mathrm{pH}$ of the solution was noted as 10.2. The solution was concentrated to approximately $3 \mathrm{~mL}$, via rotary evaporation, and a white solid was precipitated with anhydrous ethanol. The solid was isolated by centrifugation at $4000 \mathrm{rpm}$ at room temperature for $10 \mathrm{~min}$, and the ethanol decanted off. The solid was triturated with copious diethyl ether to remove excess ethanol, recentrifuged as before, the ether decanted off, and the solid dried in vacuo overnight. The dried white material was collected, and the yield obtained. The solubility of $\mathrm{MgG}_{3}$ was determined to be $169 \pm 12.5 \mathrm{~g} / 100 \mathrm{~mL} \mathrm{H}_{2} \mathrm{O}$ and the purity was found to be $90+\%$ via ${ }^{1} \mathrm{H}-\mathrm{NMR}$ integration.

\subsection{Determining Magnesium Uptake in CaCo-2 Human Cells}

Sample solutions for use with the colorimetric assay were prepared in house-each sample being $150 \mu \mathrm{M}$. The samples tested included magnesium chloride $\left(\mathrm{MgCl}_{2}\right)$, magnesium bisglycinate $(\mathrm{MgBG})$ and $\mathrm{MgG}_{3}$. Each well contained a total volume of $150 \mu \mathrm{L}(50 \mu \mathrm{L}$ of cells in ultrapure $\mathrm{H}_{2} \mathrm{O}, 50 \mu \mathrm{L}$ of buffer/enzyme/developer mix, and varying amounts of sample from 0 to $20 \mu \mathrm{L}$ brought to total volume with $18.2 \mathrm{M} \Omega \mathrm{H}_{2} \mathrm{O}$ to desired well concentration). To conduct the assay, $50 \mu \mathrm{L}$ of cells in ultrapure $\mathrm{H}_{2} \mathrm{O}$ was added to each well with a multichannel micropipette. Subsequently, the required volume of sample was added to each well and brought to volume with ultrapure $\mathrm{H}_{2} \mathrm{O}$. To ensure a consistent starting time point, $50 \mu \mathrm{L}$ of the magnesium buffer/enzyme developer mix was added to each well with a multichannel micropipette. The plate was incubated for approximately $1 \mathrm{~h}$ and then placed in a Flexstation 3 plate-reading spectrofluorometer to analyze well absorbance at $450 \mathrm{~nm}$. Each well was analyzed at $37^{\circ} \mathrm{C}$ for endpoint value over nine full plate scans with 3 scans/well/plate scan (a total of 27 scans per well) and the reported value of each well was the average value of these scans after background subtraction. Data was collected at 1 , 4 and $24 \mathrm{~h}$. Raw data was reduced and plotted as absorbance value against the magnesium concentration of each well. All assays were repeated as triplicate independent runs-error bars shown in graph (Figure 7). All data shown as $\pm \mathrm{SEM}\left(\mathrm{MgCl}_{2}=0.029, \mathrm{MgBG}=0.025\right.$, $\mathrm{MgG}_{3}=0.053$; Upper 95\% C.I.: $\mathrm{MgCl}_{2}=0.168, \mathrm{MgBG}=0.123, \mathrm{MgG}_{3}=0.278$; Lower $95 \%$ C.I.: $\left.\mathrm{MgCl}_{2}=0.031, \mathrm{MgBG}=0.001, \mathrm{MgG}_{3}=0.024\right)$.

\section{Conclusions}

The facile synthesis of a new magnesium chelate, $\mathrm{MgG}_{3}$, was successfully accomplished at near stoichiometric yield, utilizing a magnesium oxide starting material and citric acid at a $0.5 \mathrm{M}$ equivalent. The characterization of the complex via both $1 \mathrm{D}$ and $2 \mathrm{D}$ NMR showed the free ligand $\mathrm{HG}_{3}$ to act as a tetradentate ligand, and the overall complex to exhibit six-coordinate pseudo-octahedral geometry with the remaining two coordination sites being occupied by water, and inherent charge balance being achieved via a hydroxy anion-as was determined via TGA/DSC and elemental analysis. The complex exhibited exceptional water solubility $(169 \pm 12.5 \mathrm{~g} / 100 \mathrm{~mL})$. It is believed that this increase in water solubility, due to the triglycine ligand, promotes the observed improved cellular uptake in HEK293 and CaCo-2 cell lines, relative to currently on-the-market magnesium supplements-with $\mathrm{MgG}_{3}$ showing significantly greater cellular uptake in CaCo-2 cells at concentrations ranging from $0-30 \mathrm{mmol}$, with a magnesium composition of $9 \%$, relative to $14 \%(\mathrm{MgBG})$ and $25 \%\left(\mathrm{MgCl}_{2}\right)$, respectively. These findings suggest $\mathrm{MgG}_{3}$ may be a new nutraceutical/pharmaceutical and provide positive insight into further use of naturally occurring tripeptides as metal chelates to aid in complex stability and the bioavailability of other micronutrient nutraceuticals.

\section{Patents}

U.S. Patent \# 63032955 filed 6/1/2020.

Supplementary Materials: Supplementary materials are provided as a Microsoft Word document. The document includes supplemental $\mathrm{MgG}_{3}$ characterization data, full spectra ${ }^{1} \mathrm{H} /{ }^{13} \mathrm{C}-\mathrm{NMR}$ of $\mathrm{HG}_{3} / \mathrm{MgG}_{3}$, synthetic conditions evaluation at higher citric acid concentrations via ${ }^{1} \mathrm{H} /{ }^{13} \mathrm{C}-\mathrm{NMR}$, and uptake of $\mathrm{MgG}_{3}$ in HEK293 cells. 
Author Contributions: R.P.D. and R.G. conceptualized the project. R.P.D. and J.Z. mentored D.R.C. All experiments were conducted by D.R.C. Data was analyzed by all authors. The paper was drafted in the main by D.R.C. and R.P.D. with all authors contributing to the final version. All authors have read and agreed to the published version of the manuscript.

Funding: This research was funded by Balchem Corp. (New Hampton, NY, USA) to R.P.D.

Institutional Review Board Statement: Not applicable.

Informed Consent Statement: Not applicable.

Data Availability Statement: The data presented in this study are available on request from the corresponding author.

Conflicts of Interest: RG is an employee of Balchem Corporation who manufacture magnesium chelates. RPD is a paid scientific advisory board member of Balchem Corp.

Sample Availability: Samples of the compound $\mathrm{MgG}_{3}$ are available, within reason and pending approval from Balchem Corp., from RPD at Syracuse University.

\section{References}

1. Jahnen-Dechent, W.; Ketteler, M. Magnesium basics. CKJ Clin. Kidney J. 2012, 5 (Suppl. 1). [CrossRef]

2. Geiger, H.; Wanner, C. Magnesium in disease. CKJ Clin. Kidney J. 2012, 5 (Suppl. 1). [CrossRef] [PubMed]

3. De Baaij, J.H.F.; Hoenderop, J.G.J.; Bindels, R.J.M. Magnesium in man: Implications for health and disease. Physiol. Rev. 2015, 95, 1-46. [CrossRef] [PubMed]

4. Vormann, J. Magnesium: Nutrition and metabolism. Mol. Aspects Med. 2003, 24, 27-37. [CrossRef]

5. DiNicolantonio, J.J.; O'Keefe, J.H.; Wilson, W. Subclinical magnesium deficiency: A principal driver of cardiovascular disease and a public health crisis. Open Hear. 2018, 5, e000668. [CrossRef]

6. Rude, R.K.; Gruber, H.E. Magnesium deficiency and osteoporosis: Animal and human observations. J. Nutr. Biochem. 2004, 15, 710-716. [CrossRef] [PubMed]

7. Workinger, J.L.; Doyle, R.P.; Bortz, J. Challenges in the diagnosis of magnesium status. Nutrients 2018, 10, 1202. [CrossRef] [PubMed]

8. Costello, R.B.; Elin, R.J.; Rosanoff, A.; Wallace, T.C.; Guerrero-Romero, F.; Hruby, A.; Lutsey, P.L.; Nielsen, F.H.; Rodriguez-Moran, M.; Song, Y.; et al. Perspective: The Case for an Evidence-Based Reference Interval for Serum Magnesium: The Time Has Come. Adv. Nutr. Int. Rev. J. 2016, 7, 977-993. [CrossRef]

9. Al Alawi, A.M.; Majoni, S.W.; Falhammar, H. Review Article Magnesium and Human Health: Perspectives and Research Directions. Int. J. Endocrinol. 2018, 2018, 9041694. [CrossRef] [PubMed]

10. Piuri, G.; Zocchi, M.; Porta, M.D.; Ficara, V.; Manoni, M.; Zuccotti, G.V.; Pinotti, L.; Maier, J.A.; Cazzola, R. Magnesium in Obesity, Metabolic Syndrome, and Type 2 Diabetes. Nutrients 2021, 2, 1-16.

11. Razzaque, M.S.; Al Alawi, A.M.; Majoni, S.W.; Falhammar, H.; Piuri, G.; Zocchi, M.; Porta, M.D.; Ficara, V.; Manoni, M.; Zuccotti, G.V.; et al. Magnesium: Are we consuming enough? Nutrients 2018, 10, 1863. [CrossRef] [PubMed]

12. Olza, J.; Aranceta-bartrina, J.; Gonz, M.; Ortega, R.M. Reported Dietary Intake, Disparity between the Adequacy and Food Sources of Calcium, Phosphorus, Magnesium and Vitamin D in the Spanish Population: Findings from the ANIBES Study. Nutrients 2017, 9, 168. [CrossRef] [PubMed]

13. Elin, R.J. Magnesium Metabolism in Health and Disease. Disease-A-Month 1988, 34, 166-218. [CrossRef]

14. Ford, E.S.; Mokdad, A.H. Nutritional Epidemiology—Research Communication Dietary Magnesium Intake in a National Sample of U.S. Adults. J. Nutr. 2003, 133, 2879-2882. [CrossRef] [PubMed]

15. Mizushima, S.; Cappuccio, F.P.; Nichols, R.; Elliott, P. Dietary magnesium intake and blood pressure: A qualitative overview of the observational studies. J. Hum. Hypertens. 1998, 12, 447-453. [CrossRef]

16. Altura, B.M.; Altura, B.T. Tension headaches and muscle tension: Is there a role for magnesium? Med. Hypotheses 2001, 57, 705-713. [CrossRef] [PubMed]

17. Sales, C.H.; Pedrosa Lde, F. Magnesium and diabetes mellitus: Their relation. Clin. Nutr. 2006, 25, 554-562. [CrossRef] [PubMed]

18. Cappuccio, F.P. Sodium, potassium, calcium and magnesium and cardiovascular risk. Eur. J. Prev. Cardiol. 2000, 7, 1-3. [CrossRef] [PubMed]

19. Hayhoe, R.P.G.; Lentjes, M.A.H.; Luben, R.N.; Khaw, K.T.; Welch, A.A. Dietary magnesium and potassium intakes and circulating magnesium are associated with heel bone ultrasound attenuation and osteoporotic fracture risk in the EPIC-Norfolk cohort study. Am. J. Clin. Nutr. 2015, 102, 376-384. [CrossRef] [PubMed]

20. Brauman, J.; Schoutens, A. Bone Mineral Content of the Radius: Good Correlations With Physicochemical Determinations in Iliac Crest Trabecular Bone of Normal and Osteoporotic Subjects. Metabolism 1981, 30, 57-62.

21. Classen, H.-G.; Kisters, K. Magnesium and osteoporosis. Trace Elem. Electrolytes 2017, 34, 100-103. [CrossRef]

22. Kass, L.; Weekes, J.; Carpenter, L. Effect of magnesium supplementation on blood pressure: A meta-analysis. Eur. J. Clin. Nutr. 2012, 66, 411-418. [CrossRef] [PubMed] 
23. Crook, M.; Couchman, S.; Tutt, P.; Amiel, S.; Swaminathan, R. Erythrocyte, plasma total, ultrafiltrable and platelet magnesium in type 2 (non-insulin dependent) diabetes mellitus. Diabetes Res. 1994, 27, 73-79. [PubMed]

24. Guerrera, M.; Volpe, S.; Mao, J. Therapeutic Uses of Magnesium. Am. Fam. Physician 2009, 80, 157-162. [PubMed]

25. Ropp, R.C. Group 16 (O, S, Se, Te) Alkaline Earth Compounds; Newnes: Londong, UK, 2013; Volume 16, ISBN 9780444595508.

26. Perry, D.L. Handbook of Inorganic Compounds, 2nd ed.; CRC Press: Boca Raton, FL, USA, 2011; Volume 33, ISBN 9781439814628.

27. Clynne, M.A.; Potter, R.W. Solubility of Some Alkali and Alkaline Earth Chlorides in Water at Moderate Temperatures. J. Chem. Eng. Data 1979, 24, 338-340. [CrossRef]

28. Kanunnikova, O.M.; Aksenova, V.V.; Karban, O.V.; Muhgalin, V.V.; Senkovski, B.V.; Ladjanov, V.I. Mechanical activation effect on structure, physicochemical, and biological properties of potassium/magnesium orotates. IOP Conf. Ser. Mater. Sci. Eng. 2018, 283. [CrossRef]

29. McCarty, M.F. Magnesium Taurate and Other Mineral Taurates. U.S. Patent 5,582,839, 10 December 1996.

30. Apelblat, A.; Manzurola, E. Solubilities of o-acetylsalicylic, 4-aminosalicylic, 3,5-dinitrosalicylic, and p-toluic acid, and magnesiumDL-aspartate in water from $\mathrm{T}=(278$ to 348$) \mathrm{K}$. J. Chem. Thermodyn. 1999, 31, 85-91. [CrossRef]

31. Liu, G.; Mao, F. Slow Release Magnesium Composition and Uses Thereof. U.S. Patent 8,377,473 B2, 19 February 2013.

32. Younes, M.; Aggett, P.; Aguilar, F.; Crebelli, R.; Dusemund, B.; Filipič, M.; Frutos, M.J.; Galtier, P.; Gundert-Remy, U.; Kuhnle, G.G.; et al. Evaluation of di-magnesium malate, used as a novel food ingredient and as a source of magnesium in foods for the general population, food supplements, total diet replacement for weight control and food for special medical purposes. EFSA J. 2018, 16. [CrossRef]

33. Hartle, J.; Ashmead, S.D.; Kreitlow, R. Dimetal Hydroxy Malates. U.S. Patent 6,706,904, 16 March 2004.

34. Mühlbauer, B.; Schwenk, M.; Coram, W.M.; Antonin, K.H.; Etienne, P.; Bieck, P.R.; Douglas, F.L. Magnesium-L-aspartate-HCl and magnesium-oxide: Bioavailability in healthy volunteers. Eur. J. Clin. Pharmacol. 1991, 40, 437-438. [CrossRef] [PubMed]

35. Firoz, M.; Graber, M. Bioavallability of US commercial magnesium preparations. Magnes. Res. 2001, 14, 257-262. [PubMed]

36. Kappeler, D.; Heimbeck, I.; Herpich, C.; Naue, N.; Höfler, J.; Timmer, W.; Michalke, B. Higher bioavailability of magnesium citrate as compared to magnesium oxide shown by evaluation of urinary excretion and serum levels after single-dose administration in a randomized cross-over study. BMC Nutr. 2017, 3, 1-12. [CrossRef]

37. Thongon, N.; Krishnamra, N. Omeprazole decreases magnesium transport across Caco-2 monolayers. World J. Gastroenterol. 2011, 17, 1574-1583. [CrossRef]

38. Thongon, N.; Krishnamra, N. Apical acidity decreases inhibitory effect of omeprazole on Mg2+ absorption and claudin-7 and -12 expression in Caco-2 monolayers. Exp. Mol. Med. 2012, 44, 684-693. [CrossRef]

39. Coudray, C.; Feillet-Coudray, C.; Rambeau, M.; Tressol, J.C.; Gueux, E.; Mazur, A.; Rayssiguier, Y. The effect of aging on intestinal absorption and status of calcium, magnesium, zinc, and copper in rats: A stable isotope study. J. Trace Elem. Med. Biol. 2006, 20, 73-81. [CrossRef]

40. Blaquiere, C.; Berthon, G. Speciation studies in relation to magnesium bioavailability. Formation of Mg(II) complexes with glutamate, aspartate, glycinate, lactate, pyroglutamate, pyridoxine and citrate, and appraisal of their potential significance towards magnesium gastrointestin. Inorg. Chim. Acta 1987, 135, 179-189. [CrossRef]

41. Hartshorn, R.M.; Hellwich, K.H.; Yerin, A.; Damhus, T.; Hutton, A.T. Brief guide to the nomenclature of inorganic chemistry. Pure Appl. Chem. 2015, 87, 1039-1049. [CrossRef]

42. Fowden, L.; Smith, A. Peptides From Blighia Sapida Seed. Phytochemistry 1969, 8, 1043-1045. [CrossRef]

43. Yin, L.H.; Liu, X.P.; Yi, L.Y.; Wang, J.; Zhang, Y.J.; Feng, Y.F. Structural characterization of calcium glycinate, magnesium glycinate and zinc glycinate. J. Innov. Opt. Health Sci. 2017, 10, 1-10. [CrossRef]

44. Schmidbaur, H.; Classen, H.G.; Helbig, J. Aspartic and Glutamic Acid as Ligands to Alkali and Alkaline-Earth Metals: Structural Chemistry as Related to Magnesium Therapy. Angew. Chem. Int. Ed. Engl. 1990, 29, 1090-1103. [CrossRef]

45. Murphy, C.B.; Martell, A.M. Metal Chelates of Glycine and Glycine Peptides. J. Biol. Chem. 1957, 226, 37-50. [CrossRef]

46. Sambuy, Y.; De Angelis, I.; Ranaldi, G.; Scarino, M.L.; Stammati, A.; Zucco, F. The Caco-2 cell line as a model of the intestinal barrier: Influence of cell and culture-related factors on Caco-2 cell functional characteristics. Cell Biol. Toxicol. 2005, $21,1-26$. [CrossRef] [PubMed]

47. Sánchez, B.M.; Cabarga, M.M.; Navarro, A.S.; Hurlé, A.D.G. A physico-chemical study of the interaction of ciprofloxacin and ofloxacin with polivaient cations. Int. J. Pharm. 1994, 106, 229-235. [CrossRef]

48. Drevenšek, P.; Košmrlj, J.; Giester, G.; Skauge, T.; Sletten, E.; Sepčić, K.; Turel, I. X-Ray crystallographic, NMR and antimicrobial activity studies of magnesium complexes of fluoroquinolones-racemic ofloxacin and its S-form, levofloxacin. J. Inorg. Biochem. 2006, 100, 1755-1763. [CrossRef] [PubMed]

49. Storm, C.B.; Corwin, A.H. Proton Magnetic Resonance Evidence for Ligand-Porphyrin Interaction in Magnesium Porphyrins. J. Org. Chem. 1964, 29, 3700-3702. [CrossRef]

50. Leifer, A.; Lippincott, E.R. The Infrared Spectra of Some Amino Acids. J. Am. Chem. Soc. 1957, 79, 5098-5101. [CrossRef]

51. Maguire, M.E.; Cowan, J.A. Magnesium chemistry and biochemistry. BioMetals 2002, 15, 203-210. [CrossRef] [PubMed]

52. Black, C.B.; Huang, H.W.; Cowan, J.A. Biological coordination chemistry of magnesium, sodium, and potassium ions. Protein and nucleotide binding sites. Coord. Chem. Rev. 1994, 135-136, 165-202. [CrossRef]

53. Dudev, T.; Cowan, J.A.; Lim, J.A. Competition between Protein Ligands and Cytoplasmic Inorganic Anions for the Metal Cation: A DFT/CDM Study. J. Am. Chem. Soc. 1999, 121, 7665-7673. [CrossRef] 
54. Burgess, M.A. Metal Ions in Solution; Horwood, E., Ed.; Prentice Hall: London, UK, 1978.

55. Ivanova, B.; Kolev, T.; Zareva, S. Solid-State IR-LD Spectroscopic and Theoretical Analysis of Glycine-Containing Peptides and Their Hydrochlorides. Biopolymers 2006, 82, 587-596. [CrossRef] [PubMed]

56. Jabbari, M.; Gharib, F. Equilibrium studies of triphenyltin(IV) complexes with glycine, glycyl-glycine, and glycyl-glycyl-glycine in different aqueous solutions of ethanol. Can. J. Chem. 2010, 88, 877-885. [CrossRef]

57. Manyak, A.R.; Murphy, C.B.; Martell, A.E. Metal chelate compounds of glycylglycine and glycylglycylglycine. Arch. Biochem. Biophys. 1955, 59, 373-382. [CrossRef]

58. Van der Helm, D.; Willoughby, T.V. The crystal structure of $\mathrm{CaCl}_{2} \bullet$ glycylglycylglycine $\bullet 3 \mathrm{H}_{2} \mathrm{O}$. Acta Crystallogr. Sect. B Struct. Crystallogr. Cryst. Chem. 1969, 25, 2317-2326. [CrossRef]

59. Srikrishnan, T.; Winiewicz, N.; Parthasarathy, R. New patterns of hydrogen bonded interactions between polypeptide chains: Crystal and molecular structure of glycylglycylglycine. Int. J. Pept. Protein Res. 1982, 19, 103-113. [CrossRef] [PubMed]

60. Fine, K.D.; Santa Ana, C.A.; Porter, J.L.; Fordtran, J.S. Intestinal absorption of magnesium from food and supplements. J. Clin. Investig. 1991, 88, 396-402. [CrossRef] [PubMed]

61. Schuette, S.A.; Ziegler, E.E.; Nelson, S.E.; Janghorbani, M. Feasibility of using the stable isotope $25 \mathrm{Mg}$ to study mg metabolism in infants. Pediatr. Res. 1990, 27, 36-40. [CrossRef] [PubMed]

62. Sabatier, M.; Grandvuillemin, A.; Kastenmayer, P.; Aeschliman, J.M.; Bouisset, F.; Arnaud, M.J.; Dumoulin, G.; Berthelot, A. Influence of the consumption pattern of magnesium from magnesium-rich mineral water on magnesium bioavailability. Br. $\mathrm{J}$. Nutr. 2011, 106, 331-334. [CrossRef] [PubMed]

63. Younes, H.; Demigné, C.; Rémésy, C. Acidic fermentation in the caecum increases absorption of calcium and magnesium in the large intestine of the rat. Br. J. Nutr. 2005, 75, 301-314. [CrossRef] 